\title{
The Impact of Foreign Direct Investment on Economic Growth in Nigeria.
}

\author{
${ }^{1}$ Fredrick Onyebuchi Asogwa (PhD) and ${ }^{2}$ Manasseh, Charles Osondu \\ ${ }^{1,2}$ Department of Economics, University of Nigeria, Nsukka. Enugu State. South-East Nigeria. West Africa.
}

\begin{abstract}
This study investigates the impact of FDI on economic growth. Quarterly data is used and covers the period 1980Q1-2009Q4. Endogenous growth model is employed for the study with emphases on the impact of FDI inflow into agriculture, manufacturing and telecommunication sectors in Nigeria. However, the study also examines the direction of causality between FDI inflow into these sectors and economic growth. In addition, the study further investigate the influence of business environment - political instability (PI), corruption (CRPINDX), institution/legal framework (LEGFRWK) proxied by FH, 2001, suggested by work of Sala-i-Martin (1997) and Barro and Lee (1994) and macroeconomic indicators such as inflation (INF), real interest rate (RINTR) and real exchange rate (RER) on the inflow of FDI. The empirical evidence shows that FDI into manufacturing and telecommunication sector has positive impact on economic growth in Nigeria while FDI into agricultural sector impacted on economic growth negatively. The findings on granger causality suggest that FDI into agriculture, manufacturing and telecommunication sector have a unidirectional relationship with economic growth in Nigeria. Institution or legal framework has positive and significant influence on the inflow of FDI, hence suggesting the need for strong legal framework for property right protection could serve as an incentive to attract more foreign investors. Political instability and real exchange rate significantly and negatively influences the inflow of FDI vis-a-vis signifying the importance of friendly business environment in the country.
\end{abstract}

Keywords: Investment, Business, environment, Causality, Macroeconomic, institution, Instability, corruption.

\section{Introduction:}

The relevance of foreign direct investment cannot be overemphasized. Its significant influence on the provision of new technologies, products, management skills and competitive business environment, overtime has been a strong impetus for economic growth. Many countries of the world, especially emerging economies faviour policies that encourages the inflow of foreign direct investment because of it positive spillover associated with the provision of funds and expertise that could help smaller companies to expand and increase international sales and transfer of technology thus, forming new varieties of capital input (i.e. flow of services available for production from the stock of capital goods e.g. equipment, structures, inventories etc) that cannot be achieved through financial investments or trade in goods and services alone.

Nigeria is one of the economies with great demand for goods and services and has attracted many FDI over the years since the discovery of crude oil. According to the World Bank, from 1970 to 1979, Nigeria recorded an average ratio of foreign direct investment net inflow of about 1.579 to GDP while from 1980 to 1989, the average ratio of FDI net inflow to GDP recorded stood at 1.947. Thus, in 1994 and 1993, the country made a remarkable record of 8.28 and 6.3 respectively. Since 1993 and 1994, the record was not an issue to contend with. To the greatest dismay, from 1995 to 2010, FDI, net inflow as \% of GDP in Nigeria has not gone beyond 4.0 except in 1996, 1997, 2005 and 2009 the country made a record of 4.51, 4.25, 4.44 and 5.08 respectively. World Bank research contained in global development finance 2008 shows that Thailand attracted $\$ 9.6$ billion in 2007 while Nigeria attracted just about $\$ 6.03$ billion. Also, CBN (2010) annual report also indicated that total foreign direct investment inflow into the Nigerian in 2010 was about $\$ 5.99$ billion. The breakdown of the amount according to the report shows that FDI portion was just 12.2 percent or $\$ 668$ million. This represents a 78.1 percent drop from $\$ 3.31$ billion in 2009. In light of the above, many Nigerians are lost in guesses of the likely causes of the insignificant inflow of FDI into the country. This has been a source of worry to both policy makers and government authorities. Amidst, Asiedu, (2005) asserted that the level of FDI attracted by Nigeria is mediocre compared with the resource based and potential need, taken into cognizance of the fact that Nigeria is the $8^{\text {th }}$ ranked most populous nation and $32^{\text {nd }}$ biggest economy in the world (CIA World fact book) with the endowment to do better than its counterpart South Africa as the Africa biggest economy following the statement of investment giant Morgan Stanley.

In view of CBN (2010) report, poor state of infrastructural facilities, high level of corruption, poor business environment/insecurity, weak institutional/legal framework, and poor property right protection has been linked to the significant drop in FDI inflow into the country in recent years. This has influenced negatively, the impact on the desires of foreign investors for Nigeria's Paper assets, thus resulting to a sharp fall in portfolio 
investments by 87.1 percent to 65.5 percent ( $\$ 3.9$ billion) capital inflows into the country in 2010 . In support of this report, Zhang, (2001) asserts that the extent to which FDI contributes to growth depends on the economic and social condition or the quality of the environment of the recipient country. Hence, World Bank/IFC (2012) latest ease of doing business equally shows that Nigeria was ranked $133 \mathrm{rd}$ out of 183 countries and $4^{\text {th }}$ (i.e. partly free) in the freedom of world country rating report associated with her political right and civil liberties while, the global anti-corruption body (Transparency International) yearly ranking of public sector transparency moved Nigeria up from $143^{\text {rd }}$ in 2011 to 139 in 2012. Even though the Federal Government dismissed the rating by Transparency International (TI), saying it was a product of "synopsis of negative media reports (Emmanuel and Agande, 2012), the fact remains that a value system that aim at ordering and prioritizing the ethics and ideology is seriously need to shape the perceptions and thinking of foreign investors about the country and to step up the inflow of FDI into the country.

In recent time, federal government of Nigeria has grown much concern over the threat and challenges facing the country. To this, many policy reforms has been initiated in order to change the belief and the value system of people on the basis of Nigerian's social, economy and the political philosophy. For example in 2007, former president of Nigeria, Alhaji Umaru Musa Yar'Adua (Late) initiated a policy reform called "Seven (7) point agenda" to address the problem of dilapidated infrastructural facilities and insecurity of lives and property. However, in 2011, President Goodluck Ebele Jonathan initiated a complementary policy tagged the transformation agenda. The agenda focused on non-inflationary growth, employment generation, poverty alleviation and value reorientation of the citizenry thereby challenging different arms and institutions of the government such as the national assembly, judiciary, electoral umpire and armed forces to stand on their feet to re-invent the wheel to property and human right protection and conducive business environment in order to exploit the inherent benefits of the agenda to promote economic growth of the country.

Furthermore, the empirical linkage between FDI and economic growth in Nigeria is yet unclear, despite numerous studies that have examined the influence of FDI on Nigeria's economic growth with varying outcomes (Adelegan, 2000 and Akinola, 2004). Thus, the relationship between FDI and growth may be country and period specific (Egbo, Nil). Asiedu (2003) submits that the determinants of FDI in one region may not be the same for other regions. Also, the determinants of FDI in countries within a region may be different from one another and from one period to another.

In the previous literature, many studies made conscious effort in revealing the causality effect and the impacts of FDI on economic growth in Nigeria with very few examining the influence of FDI into specific sectors like agricultural, manufacturing and telecommunication sector. Previous studies look at FDI in a broad term without looking at the specific sectors and it impact on the economy as at the time of this study. To the best of our knowledge, only the work of Ayanwale (2007) and Egwaikhide (2012) investigated the impact of FDI taken into consideration of specific sectors of both non-oil and oil sector respectively. Hence, Ayanwale (2007) investigate the empirical relationship between non-extractive FDI and economic growth while Egwaikhide (2012) examine the long run relation between FDI in five sectors of the economy for periods of 1980 to 2009 using Johanson cointegration test and annual data. Thus, our study intends to investigate the impacts of FDI in three sectors of the economy such as Agricultural, manufacturing and Telecommunication sector on economic growth in Nigeria, hence shading more light on the importance of development of these sectors order than the oil sector. Following the World Bank/IFC (2012) latest ease of doing business and Global Anti-corruption (Transparency International) report of 2011 and 2012 in Nigeria that shows unfavorable business environment and weak property right protection, we intend to investigate the impacts of business environment divided into political, institutional/legal framework and macroeconomic factors on FDI inflow into Nigeria for the periods of 1980 to 2009, using quarterly data. Furthermore, we further extended our investigation to the direction of causality between FDI in the three sectors and economic growth. With the inclusion of business environment, legal/institutional framework, causality test and the use of quarterly data, the study departs from the work of Ayanwale (2007) and Egwaikhide (2012).

This paper is divided into six sections. Section two is a review of literature, Section three outlines the methodology, Section four discusses the empirical findings and five the findings implication while section six is the conclusion and policy suggestions.

\subsection{Theoretical Framework:}

\section{Review of Literature:}

The divergent views of theories on the impact and determinants of inflow of FDI into recipient countries deposited a strong guess on "which is the correct theory" in the mind of every researcher. The different ideologies of theorist on the determinants of FDI and its impact emanate from the heterogeneous nature of economic environment of countries of the world. Hence, some theories believe that competition, the influence of real exchange rate and innovation is a key thing that attracts FDI while others postulated that social condition, environment, economic growth, market imperfection, technological development, labour abundant etc of the 
recipient countries play a crucial role in attracting FDI (see Vernon, 1966; Crushman, 1985; Hymer, 1976 and Dunning, 1973; 1980 and 1988). Thus, Hymer (1976), the author of the concept of firm-specific advantages demonstrates that FDI take place only if the benefits of exploiting firm-specific advantages outweigh the relative costs of the operations abroad. He further argues that the inflow of FDI to recipient economy is due to the imperfection that characterized their market while other maintain that the extent to which FDI contributes to growth depends on the economic and social condition or in short, the quality of environment of the recipient country (Buckley, Clegg, Wang, \& Cross, 2002). The quality of environment relates to the rate of savings in the host country, the degree of openness and the level of technological development. Host countries with high rate of savings, open trade regime and high technological product would benefit from increase FDI to their economies. In addition, FDI may have negative effect on the growth prospect of the recipient economy if they give rise to a substantial reverse flows in the form of remittances of profits, and dividends and/or if the transnational corporations (TNCs) obtain substantial or other concessions from the host country.

But Dunning (1988), in his eclectic theory on international production includes three variables as the major determinants FDI; ownership-specific, location-specific and internalization. The theory sometimes called "OLI framework", stands at the intersection of a macroeconomic theory of international trade and microeconomic theory of the firm. It is an exercise in resource allocation and organizational economics. The key assertion is that all three factors (OLI) are important in determining the extent and pattern of FDI. Ownershipspecific variables include tangible assets such as natural endowments, manpower, and capital but also intangible assets such as technology and information, managerial, marketing, and entrepreneurial skills, and organizational systems. Location-specific (or country-specific) variables refer to factor endowments introduced in the preceding chapter as well as market structure, government legislation and policies, and the political, legal, and cultural environments in which FDI is undertaken. Finally, internalization refers to the firm's inherent flexibility and capacity to produce and market through its own internal subsidiaries.

\subsection{Empirical Literature:}

The impacts of FDI and economic growth disparity among developing countries have created much research interest among economists. There is a large body of empirical literature on the impact of FDI on economic growth. The existing evidence, however, is mixed. In the work of Li and Liu (2005), the evidence suggests that FDI not only affects growth directly, but also indirectly through its interaction with human capital. Further, they find a negative coefficient for FDI when it is regressed with the technology gap between the source and host economy using a large sample, Borensztein et al. (1998) found similar results i.e. that inward FDI has positive effects on growth with the strongest impact, coming through the interaction between FDI and human capital. He further argue that FDI is an important vehicle for the transfer of technology, which contributes relatively more to growth than domestic investment. He added that FDI has the effect of increasing domestic investment.

De Mello (1997) found positive effects of FDI on economic growth in both developing and developed countries, but concludes that the long-run growth in host countries is determined by the spillovers of knowledge and technology from investing countries to host countries. Similarly, Balasubramanyam et al. (1996) found support for their hypotheses that the growth effect of FDI is positive for export promoting countries and potentially negative for import-substituting ones. Comparing evidence from developed and developing countries, Blonigen and Wang (2005) noted that the factors that affect FDI flows are different across the income groups. Interestingly, they find evidence of beneficial FDI only for developing countries and not for the developed ones, while they find the crowding-out effect of FDI on domestic investment to hold for the wealthy group of nations. In addition, $\mathrm{Vu}$ and Noy (2009) study on sectoral analysis of foreign direct investment and growth in developed countries with a particular emphasis on the sector impacts of FDI on growth reveal that, FDI has no statistical and positive effects on economic growth through its interaction with labour. Moreover, they found that the effects seem to be very different across countries and economic sectors. Also, using simultaneous equations model, Ruxanda and Muraru (2010) examined the relationship between FDI and economic growth in the Romanian economy. Their findings suggest a bi-directional causation between FDI and economic growth.

In Nigeria, many works have been done to establish the relationship between FDI and economic growth. Some of these works include Okon et.al, 2012, Aluko (1961), Brown (1962) and Obinna (1983), Adelegan (2000) etc. Aluko (1961), Brown (1962) and Obinna (1983) findings suggest a positive relationship between FDI and economic growth in Nigeria while Okon et.al, (2012) examine if there is any sort of feed-back relationship between FDI and economic growth in Nigeria using single and simultaneous equation systems. The results obtained show that FDI and economic growth are jointly determined in Nigeria and there is positive feedback from FDI to growth and from growth to FDI. Adelegan (2000) examine the impact of FDI on economic growth with Seemingly Unrelated Regression model. He found that FDI is pro-consumption, proimport and negatively related to gross domestic investment. In another paper, Similarly, Ayanwale and Bamire 
(2001) assessed the influence of FDI on firm level productivity in Nigeria and reported positive spillover of foreign firms on domestic firm productivity.

Accordingly, studies such as Ayanwale (2007) and Akinlo (2004) focused on the oil and non-oil sector. These studies assessed the impacts of FDI inflows to the extractive industry on Nigeria's economic growth. Akinlo (2004) specifically controlled for the non-oil FDI dichotomy in Nigeria. Using error correction model, he investigated the impact of foreign direct investment (FDI) on economic growth in Nigeria. He found that both private capital and lagged foreign capital have small and not a statistically significant effect on economic growth. Further, his results support the argument that extractive FDI might not be growth enhancing as much as manufacturing FDI. Egwaikhide (2012) also investigates the relationship between foreign direct investment (FDI) and economic growth in Nigeria, Johansen Cointegration technique and Vector Error Correction Method in which FDI is disaggregated into various components. The Johansen Cointegration result establishes that the impact of the disaggregated FDI on real growth in Nigeria namely: agriculture, mining, manufacturing and petroleum sectors is very little with the exception of the telecom sector which has a good and promising future, especially in the long run. Furthermore, past level of FDI and level of infrastructures are FDI enhancing.

Ayadi (2009) investigates the relationship between FDI and economic growth in Nigeria and discovered weak correlation and causality between the variables and recommends that infrastructural development, human capital building and strategic policies towards attracting FDI should be intensified. In the same vein, Osinubi and Amaghionyediwe (2010) examined the relationship between foreign private investment (FPI) and economic growth in Nigeria. Their findings suggest that FPI, domestic investment growth, net export growth and the lagged error term were statistically significant in explaining variations in Nigeria economic growth while Ayashagba and Abachi (2002) evidenced a significant impact on economic growth.

III. Methodology:

Following Obwona (2001) analytical framework, the county's production function is represented by the total production function, also called multi-factor productivity stated in equation 1 below:

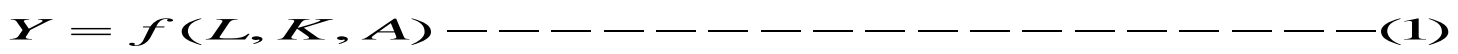

Where $\mathrm{Y}$ is the output, $\mathrm{L}$; labour force, $\mathrm{K}$; capital stock and $\mathrm{A}$ is the total factor productivity of growth in output, not accounting for increase in factor outputs ( $\mathrm{K}$ and $\mathrm{L})$.

The study employs the endogenous growth model specified in equation 2 below.

$$
Y_{i t}=F\left(K_{i t}, A(t) L_{i t}\right)----------------(2)
$$

According to endogenous growth theory, A is endogenously determined by economic factors. Adopting the method of Lipsey (2001) which has been used by Egwaikhide (2012), local and foreign components of domestic investment cannot be separated due to the unavailability of data in the literature that have fully captured addition to domestic investment by foreign firm. Hence, we assume that the effect of FDI on economic growth operating through A depends on trade policy regime which we capture with trade openness (TOP). Hence, we defined;

$$
\begin{aligned}
& A_{i t}=h\left(F D I_{i t}, T O P_{i t}\right)-\ldots-\ldots-\ldots-\ldots-\ldots-\ldots-\ldots \text { (3) }
\end{aligned}
$$

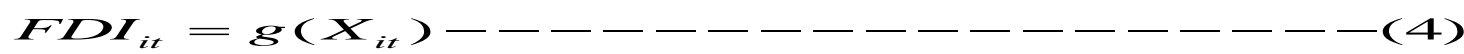

Where $\mathrm{X}_{\mathrm{it}}$ represent FDI from the three sectors of the economy such as Agricultural, Manufacturing and Telecommunication sector. Substituting equation (3) and (4) into (1), we have the reduced form equation stated below;

$$
\left.Y=F\left(L, K, X_{i t}, T O P\right)---------------15\right)
$$

Where $\mathrm{Y}$ is the output (proxy - real gross domestic product - RGDP), L; labour force measure with the population between the ages of 15 and 64 as a percentage of the total population following internal labour organization definition, $\mathrm{K}$; is capital stock measured by real gross fixed capital formation as percentage of GDP. It should be noted that this proxy has been used by Athukorala (2003), Ayanwale (2007) and Egwaikhide (2012). $X_{\mathrm{it}}$ is measured by FDI in the three sectors chosen for the study (e.g. Agricultural, manufacturing and Telecommunication sector) while we proxy trade openness policy (TOP) with the summation of exports and 
The Impact of Foreign Direct Investment on Economic Growth in Nigeria.

imports of goods and services measured as a share of gross domestic product. Thus, the model is specified as follows:

$$
Y=F(L, K, F D I A g, F D I M a n, F D I T e l, T O P)------------------(6)
$$

\section{Model Specification:}

There is no doubt that the major stage in a study of the relationship between foreign direct investment and economic growth is the ability to specify a precise model to capture the impact of FDI on growth. Thus, our analysis will be based on the linear model specified in equation (7) below:

$\ln Y_{t}=\beta_{0}+\beta_{1} \ln L_{t}+\beta_{2} \ln K_{t}+\beta_{3} \ln F_{D I A g_{t}}+\beta_{4} \ln$ FDIMan $_{t}+\beta_{5} \ln$ FDITel $_{t}+\beta_{6} \ln T O P_{t}+\varepsilon_{i t}-----(7)$

Where $\mathrm{Y}$ is real gross domestic product (RGDP), L; the population between the ages of 15 and 64 as a percentage of the total population (POP), K; real gross fixed capital formation (RGFCF) as percentage of GDP, FDIAg; foreign direct investment into agricultural sector, FDIMan; foreign direct investment into manufacturing sector, FDITel; foreign direct investment into telecommunication, TOP; trade openness policy and $\varepsilon_{\mathrm{t}}$ is the error term; $\beta_{0}$ is the intercept while $\beta_{\mathrm{i}}$ is the coefficients of the variables to be estimated. We expected positive signs for all the explanatory variables in the model.

Consideration the World Bank/IFC (2012) latest ease of doing business report, and Global Anticorruption (Transparency International) report of 2011 and 2012 in Nigeria respectively that suggest unfavorable business environment and weak institution/legal framework for property right protection as a major concern in the country, a separate model is therefore specified to investigate the influence of business environment divided into political, institution/legal framework and macroeconomic factors on FDI which form the second objective of the study. Thus, we have;

$$
F D I_{t}=\varphi_{0}+\varphi_{1} P I_{t}+\varphi_{2} \operatorname{Crptn}_{t}+\varphi_{3} \operatorname{LegFrwk}_{t}+\varphi_{4} \operatorname{Inf}_{t}+\varphi_{5} R \text { int } r_{t}+\varphi_{6} R E r_{t}+\mu_{i t}----(8)
$$

We used dummy variable to measure political instability (PI). Political instability takes values of one (1), if there is no military coup and zero (0), if government is interrupted by military coup. Institutional or legal framework (LEGFRWK) is proxied with freedom house index (FH, 2001) suggested by work of Barro and Lee (1994), Sala-i-Martin (1997) and De Melo et al. (1997) and corruption measured with corruption index (CRPINDX) while inflation (INF), real interest rate (RINTR) and real exchange rate (RER) are some of the macroeconomic variables considered in the study. Inflation as measured by the consumer price index which reflects the annual percentage change in the cost to the average consumer of acquiring a basket of goods and services that may be fixed or changed at specified intervals may be yearly (WDI). Real exchange rate is the nominal effective exchange rate index $(2005=100)$ which measures the values of a currency against a weighted average of several foreign currencies divided by a price deflator or index of costs (WDI). $\varphi_{0}$ is the intercept and $\varphi_{1}, \varphi_{2}, \varphi_{3}, \varphi_{4}, \varphi_{5}$ and $\varphi_{6}$ are the coefficients of the explanatory variables. $\mu_{\mathrm{it}}$ is the error term.

\section{Granger Causality Test:}

To establish the causation between the $\mathrm{FDI}_{\mathrm{i}}$ and economic growth which form third objective of the study, we adopted Granger Causality test denoted by the following equations (Deb et al, 2008).

$$
\begin{aligned}
& y_{t}=\beta_{0}+\sum_{k=1}^{m} \beta_{k} y_{t-k}+\sum_{t=1}^{n} \alpha_{t} x_{t-1}+\mu_{t}----------(9)
\end{aligned}
$$

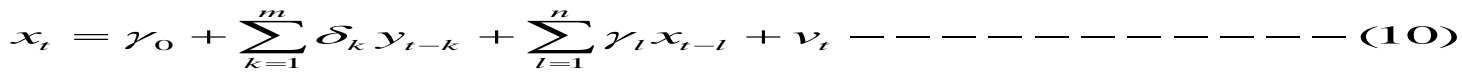

Where: $\mu_{t}$ and $v_{t}$ are mutually uncorrelated error terms and ' $\mathrm{k}$ ' and ' $\mathrm{l}$ ' are the number of lags. Granger causality assume $\alpha_{l}=0$ and $\delta_{k}=0$ for all $l^{\prime} s$ and $k^{\prime} s$ for null hypothesis. If the coefficient $\alpha_{l}^{\prime} s$ are statistically significant when $\delta_{k}^{\prime} s$ are not, then $x$ granger causes $y$. If otherwise, $y$ granger causes $x$. But in a situation where $\alpha_{l}$ and $\delta_{k}$ are significant, the causality run both direction.

\section{Source of Data:}

The data for this research work is generated from the World Development Indicator. The data on the FDIAg, FDIMan and FDITel were generated from the work of Egwaikhide (2012) which he source from the CBN statistical bulletin (2009). 


\section{Discussion of the Empirical Findings:}

The results of the Unit Root Test shown in table 4.1 indicate that all the variables are integrated of order one I(1) both at 1\%, 5\% and 10\% critical value. Only FDIAg, FDIMan and FDITel variables are stationary with intercept but not trended.

Table 4.1

\begin{tabular}{|c|c|c|c|c|c|c|}
\hline \multirow[t]{2}{*}{ Variables } & \multirow[t]{2}{*}{ ADF test Stat } & \multicolumn{3}{|c|}{ Critical Value } & \multirow{2}{*}{$\begin{array}{l}\text { Trend and } \\
\text { Intercept }\end{array}$} & \multirow{2}{*}{$\begin{array}{ll}\text { Order } & \text { of } \\
\text { Integration } & \end{array}$} \\
\hline & & $1 \%$ & $5 \%$ & $10 \%$ & & \\
\hline LOG(RGDP) & -6.755584 & -2.5838 & -1.9428 & -1.6172 & None & $\mathrm{I}(1)$ \\
\hline LOG(POP) & -7.258258 & -2.5838 & -1.9428 & -1.6172 & None & $\mathrm{I}(1)$ \\
\hline LOG(RGFCF) & -5.00403 & -2.5838 & -1.9428 & -1.6172 & None & $\mathrm{I}(1)$ \\
\hline LOG(FDIAg) & -4.613967 & -3.4885 & -2.8868 & -2.5801 & Intercept & $\mathrm{I}(1)$ \\
\hline LOG(FDIMan) & -4.985021 & -3.4885 & -2.8868 & -2.5801 & Intercept & $\mathrm{I}(1)$ \\
\hline LOG(FDITel) & -3.581674 & -3.4885 & -2.8868 & -2.5801 & Intercept & $\mathrm{I}(1)$ \\
\hline LOG(TOP) & -3.791040 & -2.5838 & -1.9428 & -1.6172 & None & $\mathrm{I}(1)$ \\
\hline ECM(-1) & -8.016672 & -3.4880 & -2.8865 & -2.5799 & Intercept & $\mathrm{I}(0)$ \\
\hline
\end{tabular}

From the unit root test result, it was obvious that the explanatory variables are integrated of the same order with the dependent variable (RGDP) which suggests that the variables are cointegrated. To solve the cointegration problem we subject the generated residuals to unit root test. The result shows that ECM (-1) is significant at $1 \%, 5 \%$ and $10 \%$ critical value which means a long run disequilibrium in the model. Thus, indicating the importance of inclusion of ECM (-1) in the regression model.

Table 4.2

\begin{tabular}{|l|l|l|l|l|}
\hline Variable & Coefficient & t-Statistics & Std Error & Prob. \\
\hline LOG_POP & 0.482807 & 2.533185 & 0.190593 & 0.0127 \\
\hline LOG_RGFCF & 0.023529 & 0.291797 & 0.080635 & 0.7710 \\
\hline LOG_FDIAG & -0.045562 & -0.975278 & 0.046717 & 0.3315 \\
\hline LOG_FDIMAN & 0.035325 & 0.740317 & 0.047716 & 0.4607 \\
\hline LOG_FDITEL & 0.232268 & 4.024842 & 0.057709 & 0.0001 \\
\hline LOG_TOP & -0.046174 & -0.500529 & 0.092251 & 0.6177 \\
\hline C & 9.210445 & 13.70093 & 0.672249 & 0.0000 \\
\hline ECM(-1) & 0.042057 & 0.427322 & 0.098419 & 0.6700 \\
\hline
\end{tabular}

R- Square $=0.836562 ;$ Adjusted R-Square $=0.826255 ;$ Durbin-Watson Stat $=2.111891$

The regression result presented in table 4.2 above shows that, labour force (L) measured with the population between the ages of 15 and 64 as a percentage of the total population (POP), capital stock (K) measured with real gross fixed capital formation (RGFCF), foreign direct investment into manufacturing (FDIMan) sector and foreign direct investment into telecommunication (FDITel) sector have positive relationship with economic growth (proxy; RGDP). The result indicates that POP and FDITel exhibit significant positive impact on economic growth (RGDP) in Nigeria with t-value of 2.533185 and 4.024842 respectively while RGFCF and FDIMan exhibit insignificant positive impact on economic growth in Nigeria with t-values of 0.291797 and 0.740317 respectively. Hence, a percentage increase in labour force (proxy; POP), capital stock (proxy; RGFCF), FDIMan and FDITel causes 48\%, 2.4\%, 3.5\% and 23\% increase in economic growth (proxy; RGDP) in Nigeria respectively. However, FDIAg and trade policy (proxy; TOP) have negative impact on economic growth (proxy; RGDP) with t-values of -0.975278 and -0.500529 respectively. These suggest that a percentage decrease in FDIAg and TOP causes $4.5 \%$ and $4.6 \%$ decrease in economic growth in Nigeria cetris paribus. The measure of the goodness of fit, $\mathrm{R}^{2}$, shows that the explanatory variables explain more than $80 \%$ of total variations in the real GDP in Nigeria. Our result also shows no presence of serial autocorrelation $(\mathrm{DW}=2.11$ ) with the dependent variable (RGDP) while the rate of adjustment to equilibrium is 0.042057 with insignificant t-statistic that stood at 0.427322 .

In addition, the Pairwise granger causality test result in our study presented in table 4.3 below shows that the assumption of null hypothesis that FDI into agriculture, manufacturing and telecommunication does not granger cause economic growth (proxy; RGDP) is rejected.

Table 4.3

\begin{tabular}{|l|l|l|}
\hline Null Hypothesis & F- Statistic & Prob. \\
\hline LOG_FDIAG does not Granger Cause LOG_RGDP & 6.45953 & 0.00221 \\
\hline LOG_FDIMAN does not Granger Cause LOG_RGDP & 10.7358 & $5.4 \mathrm{E}-05$ \\
\hline LOG_FDITEL does not Granger Cause LOG_RGDP & 16.9791 & $3.6 \mathrm{E}-07$ \\
\hline
\end{tabular}

However, since we are also interest in the direction of causality between foreign direct investment into agriculture (FDIAg), manufacturing (FDIMan), telecommunication (FDITel) sector and economic growth 
(proxy; RGDP) which serve as the variables of interest in the study, the Pairwise granger causality test result on FDI were picked from the entire causality test result and presented in table 4.3 for simplicity. Hence, from the result, it is evidence that foreign direct investment into agriculture (FDIAg), manufacturing (FDIMan) and telecommunication (FDITel) sectors causes economic growth (RGDP) in Nigeria. Thus, the result suggests a unidirectional causation running from FDIAg, FDIMan and FDITel to economic growth (proxy; RGDP) in Nigeria.

To investigate the influence of business environment which we divided into political, institution/legal framework and macroeconomic factors on FDI that form the second objective of the study, we therefore regress model in equation 8 above. But before the regression, we subjected the variables such foreign direct investment (FDI), political instability (PI), corruption index (CRPINDX), institutional/legal framework (LEGFRWK), inflation (INF), real interest rate (RINTR) and real exchange rate (RER) to unit root test in order to avoid sporous result. The result of the test is presented on table 4.4 below. However, political instability is measured with dummy variable (e.g. no military coup $=1$ and military coup $=0$ ) while institutional/legal framework is proxied with freedom house index (FH, 2001) and corruption measured with corruption index. The macroeconomic variables included in this study are; inflation, real interest rate and real exchange rate.

Table 4.4

\begin{tabular}{|c|c|c|c|c|c|c|}
\hline \multirow[t]{2}{*}{ Variables } & \multirow[t]{2}{*}{ ADF test Stat } & \multicolumn{3}{|c|}{ Critical Value } & \multirow{2}{*}{$\begin{array}{l}\text { Trend and } \\
\text { Intercept }\end{array}$} & \multirow{2}{*}{$\begin{array}{l}\text { Order of } \\
\text { Integration }\end{array}$} \\
\hline & & $1 \%$ & $5 \%$ & $10 \%$ & & \\
\hline FDI & -5.222088 & -2.5838 & -1.9428 & -1.6172 & None & $\mathrm{I}(1)$ \\
\hline PI & -5.707190 & -2.5838 & -1.9428 & -1.6172 & None & $\mathrm{I}(1)$ \\
\hline CRPINDX & -4.311403 & -2.5838 & -1.9428 & -1.6172 & None & $\mathrm{I}(1)$ \\
\hline LEGFRWK & -7.757960 & -3.4880 & -2.8865 & -2.5799 & Intercept & $\mathrm{I}(0)$ \\
\hline INF & -4.024382 & -2.5838 & -1.9428 & -1.6172 & None & $\mathrm{I}(1)$ \\
\hline RINTR & -5.162136 & -2.5838 & -1.9428 & -1.6172 & None & $\mathrm{I}(1)$ \\
\hline RER & -3.389016 & -2.5838 & -1.9428 & -1.6172 & None & $\mathrm{I}(1)$ \\
\hline ECM & -5.768984 & -3.4885 & -2.8868 & -2.5801 & Intercept & $\mathrm{I}(0)$ \\
\hline
\end{tabular}

The unit root test result presented in table 4.4 above shows that all the variables are significant at $1 \%$, $5 \%$ and $10 \%$ critical value. However, the variables are integrated of the same order with no trend and intercept except legal framework (LEGFRWK) thus, indicating cointegration problem. The result of the ECM is significant at all the critical value with intercept hence, suggesting long run disequilibrium in the model. To address the long run disequilibrium problem in the model, we included ECM in the regression model. However, table 4.5 below shows the summary of the regression result.

Table 4.5

\begin{tabular}{|c|c|c|c|c|}
\hline \multicolumn{5}{|c|}{$\begin{array}{l}\text { Dependent Variable: FDI } \\
\text { Method: Least Squares } \\
\text { Sample (Adjusted): 1980:3 2009:4 } \\
\text { Included Observations: } 118 \text { after adjusting endpoints }\end{array}$} \\
\hline Variable & Coefficient & t-Statistics & Std Error & Prob. \\
\hline PI & -1.233909 & -2.790534 & 0.442177 & 0.0062 \\
\hline CRPINDX & 0.710021 & 5.141098 & 0.138107 & 0.0000 \\
\hline LEGFRWK & 0.242138 & 2.131459 & 0.113602 & 0.0353 \\
\hline INF & 0.071774 & 9.847323 & 0.007289 & 0.0000 \\
\hline RINTR & 0.029399 & 2.605453 & 0.011284 & 0.0104 \\
\hline RER & -0.004230 & -5.221188 & 0.000810 & 0.0000 \\
\hline $\mathrm{C}$ & 1.831292 & 2.453459 & 0.746412 & 0.0157 \\
\hline ECM(-1) & -0.126433 & -1.730919 & 0.073044 & 0.0863 \\
\hline R-Squared & \multicolumn{4}{|l|}{0.717247} \\
\hline Adjusted R-Squared & \multicolumn{4}{|l|}{0.699254} \\
\hline Durbin-Watson Stat & \multicolumn{4}{|l|}{1.930737} \\
\hline
\end{tabular}

From the summary of the regression result presented in table (table 4.5), we observed that all the explanatory variables such as political instability (PI), corruption (proxy - CRPINDX), institution/legal framework (LEGFRWK proxied with freedom house index (FH, 2001)), inflation (INF), real interest rate (RINTR) and real exchange rate (RER) significantly influence the inflow of foreign direct investment into Nigeria. Hence, among all the explanatory variables, political instability and real exchange rate significantly and negatively influences foreign direct investment into Nigeria and the influence of inflation on the inflow of FDI remains topmost with t-statistics of 9.847325 although positive. We also noticed significant positive influence of institution/legal framework with t-statistic (2.131459) on inflow of FDI thus supporting the aprori. This suggests that strong institution/legal framework for property right protection of foreign investors is a strong incentive to 
attract enormous FDI into the Nigerian economy. Even though, corruption (CRPINDX), inflation (INF) and real interest rate (RINTR) have positive sign as against the expected negative sign which may be as a result of the nature of the data (quarterly) or human and technical error during the data generating process, the fact remains that the significant influence of them on FDI is a strong evidence which shows that corruption and macroeconomic volatility (e.g. inflation and real interest rate) have been another source of disincentive to the inflow of FDI into Nigeria. For example, as at November 2012, inflation rate was 12.3 while real interest rate defined as the lending interest rate adjusted for inflation as measured by the GDP deflator (IMF) stood at $5.40 \%$ as of 2010. However, our findings support the CBN (2010) report of unfriendly business environment as an attribute of sharp drop in FDI inflow into the country in recent years and sharp fall in portfolio investments by 87.1 percent to 65.5 percent ( $\$ 3.9$ billion) capital inflows into the country in 2010 .

In addition, the result on table 4.5 revealed robust $\mathrm{R}$-square depicting better goodness of fit. The $\mathrm{R}^{2}$ (0.717247) shows that the explanatory variables explain more than $70 \%$ of total variations in the FDI in Nigeria. The Durbin-Watson statistic is 1.930737 showing no presence of serial autocorrelation with the dependent variable FDI while the long run disequilibrium in the model adjusted at the rate of $-0.126433 t$ to equilibrium with insignificant t-statistic (-1.730919).

\section{Implications of the Findings:}

The attempt to examine the impact of foreign direct investment on economic growth in Nigeria, the direction of causality between FDI into agriculture, manufacturing, telecommunication sector and economic growth as well as the influence of business environment on FDI yields the following key findings:

$>$ Foreign direct investment into manufacturing and telecommunication sector has positive impact on economic growth in Nigeria while FDI into agricultural sector impacted on economic growth negatively.

$>$ Foreign direct investment into agriculture, manufacturing and telecommunication sector causes economic growth in Nigeria, thus suggesting a unidirectional causation.

$>$ Institution or legal framework has positive and significant influence on the inflow of foreign direct investment into Nigerian economy, hence suggesting the need for strong legal framework for property right protection which could serve as an incentive to attract foreign investors into the economy.

$>$ Political instability and real exchange rate significantly and negatively influences the inflow of foreign direct investment into Nigeria vis-a-vis signifying the importance of friendly business environment in the country.

\section{Conclusion and Policy Suggestions:}

From the empirical evidence, we have been able to establish that foreign direct investment into manufacturing and telecommunication exhibit positive impacts on economic growth in Nigeria, therefore any policy idea directed at reducing the inflow of FDI into these sectors could endanger the rate of economic growth in Nigeria. Also authorities need to step up effort by relevant policies that could attract enormous inflow of FDI into agricultural sector which over time have been neglected due to the discovery of crude oil. Be that as it may, from the granger causality test, our findings suggest that economic growth is caused by the inflow of FDI into agriculture, manufacturing and telecommunication sector. Furthermore, in the course of investigating the influence of institution or legal system, we discovered a positive and significant influence on FDI inflow thus, suggesting the need for strong legal system for property right protection. The negative influence of political instability or political disruption on FDI inflow and the danger of macroeconomic volatility (real exchange rate) were also noticed from the findings. In conclusion, foreign direct investment inflow promote economic growth and business environment measured with political instability, corruption, institution/legal framework and macroeconomic environment significantly influence the inflow of FDI in Nigeria. Therefore, to promote growth and development in the economy, government should give priority to policies that could promote FDI inflow into the country such as tax holidays, infrastructural development, consistent power supply and good security outlet to address the issues of Boko Haram and their random bombing in some part of the country, kidnapping and Militancy. This will go a long way in creating enough job opportunities for the unemployed youth and help in check-mating the high rate of poverty in the country thereby reducing the gap between the proletariat and exploitative bourgeoisie.

\section{Reference:}

[1]. Adelegan, J.O. (2000), "Foreign direct investment and economic growth in Nigeria: A seemingly unrelated model". African Review of M oney, Finance and Banking, Supplementary issue of "Savings and development" 2000. pp.5-25. Milan, Italy.

[2]. Akinola, A.E. (2004), "Foreign direct investment and growth in Nigeria: A empirical investigation" Journal of Policy Modeling, vol. 26 No. 3 pp. $627-39$

[3]. Aluko, S.A. (1961), "Financing economic development in Nigeria". The Nigerian Journal of Economic and Social Studies, 3(1): $39-67$.

[4]. Asiedu, E. (2003), “Capital controls and foreign direct investment” World Development, 32(3): 479-90. 
[5]. Asiedu, E. (2005), "Foreign Direct Investment in Africa: The Role of Natural Resources, Market Size, Government Policy, Institution and Political Instability”. UNU/WIDER Research Paper 2005/24.World Institute for Development Economics Research, Helsinki.

[6]. Athukorala P.P.A.W (2003), "The Impact of Foreign Direct Investment on Economic Growth in Sri Lanka" Proceedings of the Paradeniya University Research Sessions. Vol 8, No.4 pp. 40-57.

[7]. Ayadi, F. S. (2009), "Foreign Direct Investment and Economic Growth in Nigeria." Proceedings of the 10th Annual Conference of LAABD.

[8]. Ayanwale, A.B. (2007), "FDI and Economic Growth: Evidence from Nigeria" AERC Research Paper 165, African Economic Research Consortium, Nairobi

[9]. Ayanwale, A.B. and A.S. Bamire (2001), "The Influence of FDI on Firm Level Productivity of Nigeria's Agro/Agro-Allied Sector". Final Report Presented to the African Economic Research Consortium, Nairobi.

[10]. Ayashagba, G.I., and P.I. Abachi (2002), "The Impact of Foreign Direct Investment On Economic Growth of the Less Developed Countries (LDCs): A Case of Nigeria (1980-1997)". Journal of Economic and Social Research, vol.1 No. 3, pp. 108-125.

[11]. Balasubramanyam, V.N., M.A. Salisu and D. Sapsford (1996), "Foreign direct investment and growth in EP and IS countries". Economic J., 106(434): 92-105.

[12]. Barro, R. and J. W. Lee. (1994), “International comparison of educational attainment”. Journal of Monetary Economics, 32(3): 36194.

[13]. Blonigen, B. and M. Wang (2005), "Inappropriate Pooling of Wealthy and Poor Countries in Empirical FDI Studies". In: Moran, T.H., E. Graham and M. Blomstrom (Eds.), Does Foreign Direct Investment Promote Development? Institute of International Economics Press, Washington, D.C.

[14]. Borensztein, E., J. Gregorio and J. Lee (1998), "How does foreign direct investment affect economic growth?” J. Inter. Econ., 45(1): 115-135.

[15]. Brown, C.V. (1962), "External economies and economic development". The Nigerian Journal of Economic and Social Studies, 4(1): $16-22$.

[16]. Cushman, D.O. (1985), "Real Exchange Rate Risk, Expectations and the Level of Direct Investment" in Review of Economics and Statistics, 67 (2), 297-308.

[17]. De Mello, L.R., (1997), "Foreign direct investment in developing countries and growth: A selective survey”. J. Dev. Stud., 34: 1-34.

[18]. Deb S.G. and Mukherjee J. (2008), "Does Stock Market Development Cause Economic Growth?" Time Series Analysis for Indian Economy. International Research Journal of Finance and Economics, 21, 142-149.

[19]. Dunning, J. H. (1973), “The determinants of international production”, Oxford Economic Papers 25.

[20]. Dunning, J. H. (1980), "Toward an eclectic theory of international production: Some empirical tests" in Journal of International Business Studies issue 11.

[21]. Dunning, J. H. (1988): "The Eclectic Paradigm of International Production: A restatement and some possible extensions", in Journal of International Business Studies issue 19 (spring).

[22]. Egbo, Macaulay D (Nil), "Foreign Direct Investment and The Performance" Proceedings of the 1st International Technology, Education And Environment Conference; African Society For Scientific Research (Assr). Email: endmac@yahoo.com

[23]. Egwaikhide Christian Imoudu (2012), "The Impact of Foreign Direct Investment on Nigeria's Economic Growth; 1980-2009: Evidence from the Johansen's Cointegration Approach" International Journal of Business and Social Science Vol. 3 No. 6;

[24]. Emmanuel, A and Agande, B. (2012), "Nigeria improves in rating" Vanguard, $6^{\text {th }}$ December, 2012. Link: http://www.vanguardngr.com/2012/12/nigeria-improves-in-corruption-rating.

[25]. Hymer, S., 1976 (1960 dissertation), "The International Operations of Nation Firms: A Study of Foreign Direct Investment", Cambridge, MLT Press.

[26]. Li, X. and X. Liu (2005), "Foreign direct investment and economic growth: An increasingly endogenous relationship". World Dev., 33(3): 393-407.

[27]. Obinna, O.E. (1983), "Diversification of Nigeria's external finances through strategic foreign direct investment". Nigerian Economic Society Annual Conference Proceedings, Jos, 13-16th May.

[28]. Obwona, Marios B. (2001), "Determinants of FDI and their Impact on Economic Growth in Uganda". African Development Review. Blackwell Publishers Oxford. UK. Pp. 46-80.

[29]. Obwona, Marios B. (2001), "Determinants of FDI and their impacts on economic growth in Uganda". African Development Review, 13:(1) 46-80. Blackwell Publishers, Oxford UK.

[30]. Okon J. U, Augustine O. J and Chuku A. C (2012), "Foreign Direct Investment and Economic Growth in Nigeria: An Analysis of the Endogenous Effects". Current Research Journal of Economic Theory 4(3): 53-66.

[31]. Osinubi, T. S. and Amaghionyeodiwe, L. A. (2010), "Foreign Private Investment and Economic Growth in Nigeria." REBS Review of Economic and Business Studies, Vol 3 Issue 1, pp. 105 - 127, June.

[32]. Oyejide T. A. (2005), "Capital Flows and Economic Transformation: A Conceptual Framework" on Proceedings of Central Bank of Nigeria 5th Annual Monetary Policy Conference with the theme "Capital Flows and Economic Transformation in Nigeria." Held at the CBN Conference Hall, Abuja. November 10th to 11th.

[33]. Richard G. Lipsey, (2001), "Understanding Technological Change," Economics Study Area Working Papers 13, East-West Center, Economics Study Area.

[34]. Ruxanda, G. and A. Muraru (2010), "Foreign direct investment and economic growth: Evidence from simultaneous equation models". Romanian J. Econ. Forecasting, 1: 45-57.

[35]. Sala-i-Martin (1997), "I just Ran Four Regression", NBER Working Paper Series. Working paper 6252. Link; http://www.nber.org/paper/w6252

[36]. Uwhejevwe, T. S. (2005), "Corruption and National Responsibility" http://www.nigeriavillagesquare.com/articles/samueluwhejevwe-togbolo/corruption-and-national-responsibility.html

[37]. Vernon R. (1966), "International investment and international trade in the product cycle". Quarterly Journal of Economics 80, pp. 190-207.

[38]. Vu, T.B. and I. Noy (2009), "Sectoral analysis of foreign direct investment and growth in the developed countries". J. Inter. Financial Markets Institutions Money, 19: 402-413.

[39]. Vu, T.B. and I. Noy, (2009), "Sectoral Analysis of Foreign Direct Investment and Growth in Developed Countries," International Financial Markets, Institutions \& Money, Vol. 19, Issue, 402-413

[40]. Zhang, K.H. (2001), "Does foreign direct investment promote economic growth? Evidence from East Asia and Latin America". Contemporary Economic Policy, 19(2, April): 175-85. 